\title{
PENGHUNI GUA KIDANG: PENJELAJAH TANGGUH DI KAWASAN KARST BLORA
}

\author{
Indah Asikin Nurani \\ (Balai Arkeologi Yogyakarta) \\ E-mail: anikardani@gmail.com
}

\begin{abstract}
ABSTRAK
Kehidupan manusia masa prasejarah merupakan kehidupan yang masih mengandalkan pada ketersediaan potensi lingkungan alam sekitarnya. Mereka akan mencari daerah-daerah yang menyediakan kebutuhan hidupnya baik sumber makanan maupun sumber bahan baku untuk peralatan. Gua Kidang, merupakan gua hunian masa prasejarah yang dihuni secara intensif dalam jangka waktu yang panjang. Bukti-bukti arkeologis hasil ekskavasi baik data artefak, ekofak maupun jejak perapian dan kubur memberikan gambaran bagaimana manusia masa itu mempertahankan hidupnya. Tulisan ini akan membahas bagaimana pola hidup manusia penghuni Gua Kidang dalam beradaptasi dengan lingkungan alam sekitarnya baik dari aspek pola makan, teknologi, dan mobilitas penghuni dalam mencari sumber pangan dan sumber bahan baku untuk peralatan sehari-hari.
\end{abstract}

Kata-kata kunci: Gua Kidang, jelajah manusia, cangkang kerang, tulang, batuan

\section{KIDANG CAVE DWELLER: INDOMITABLE EXPLORER IN BLORA KARST AREA}

\begin{abstract}
Prehistoric period of human life is relying on the availability of the potential of the surrounding natural environment in maintaining life. Prehistoric people will look for areas that provide the necessities of life either food source or sources of raw material to equipment. Kidang cave is one of prehistoric cave dwelling occupied intensively in the long term. Archaeological evidence, and traces ecofact fireplace and the grave gave an overview of how human beings to survive that period. This paper will discuss how patterns of human life of Kidang cave adapting to the natural environment on the aspects of diet, technology, and mobility of residents in search of food sources and sources of raw materials for everyday equipment.
\end{abstract}

Key words: Kidang cave, explorer, shells, bones, rocks

Berfala Arkeologi Vol 31 Edisi No. 2 / November 2011 


\section{PENDAHULUAN}

Gua Kidang merupakan salah satu gua yang berada di perbukitan gamping Zona Rembang. Zona ini membentang di belahan utara Pulau Jawa bagian timur dari Kabupaten Blora sampai Pulau Madura, yang tersingkap di permukaan sejak masa Plio-Pleistosen. Meskipun demikian, di beberapa lokasi mengalami graben dan tertutup oleh endapan Holosen dan resen (Gambar 1). Sejak masa itu pula terjadi pengangkatan Pulau Jawa di bagian utara yang diikuti proses pelipatan dan pensesaran. Selama proses tersebut berlangsung, terdapat block graben dan bagian yang naik atau host di permukaan sebagai bukit-bukit gamping yang telah mengalami pelarutan dan pensesaran tingkat lanjut. Selain itu, ekologi karstik mulai membentuk bukit karst, tower karst, dolena, ovale, aliran sungai bawah permukaan, gua karst, luweng karst, pola aliran karst multibasinal, dan tebing karst. Salah satu bentukan karst yaitu Gua Kidang dengan ekologi di sekitarnya berupa sungai multibasinal, luweng, tebing karst, dan sungai bawah permukaan (Nurani dan Hascaryo, 2011).

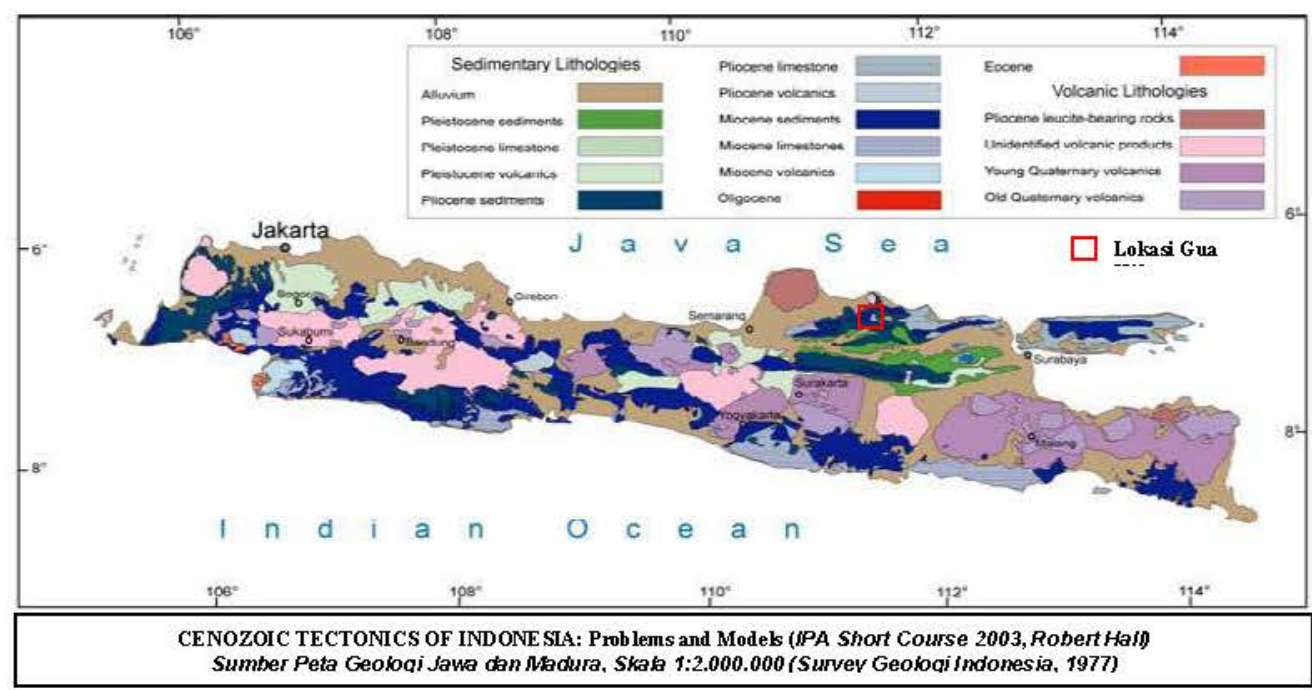

Gambar 1: Lokalitas Gua Kidang pada sebaran geologi Jawa dan Madura

Sungai multibasinal yang tampak saat ini tersebar pada daerah aliran Sungai Kedungwaru, Kedungwungu, dan Jaten. Ponor dan porus tersingkap di beberapa tempat sebagai bukti bahwa lokasi sekitar Gua Kidang adalah daerah aliran sungai bawah permukaan. Kelurusan luwengluweng terhadap lokalitas Gua Kidang juga membuktikan bahwa dahulu daerah ini memiliki sungai induk yang berada di bawah permukaan. Sungai bawah permukaan tersebut adalah cikal bakal gua-gua di ekologis karst, termasuk Gua Kidang yang pernah digunakan sebagai tempat manusia beraktivitas pada masa prasejarah. Gua-gua yang terdapat di daerah administrasi Kecamatan Todanan ini terletak di satuan batuan batu gamping 
Formasi Bulu yang bertopang pada satuan batuan Formasi Wonocolo. Peta geologi daerah situs dan sekitarnya dapat dilihat pada peta berikut ini (Nurani dan Hascaryo, 2011).

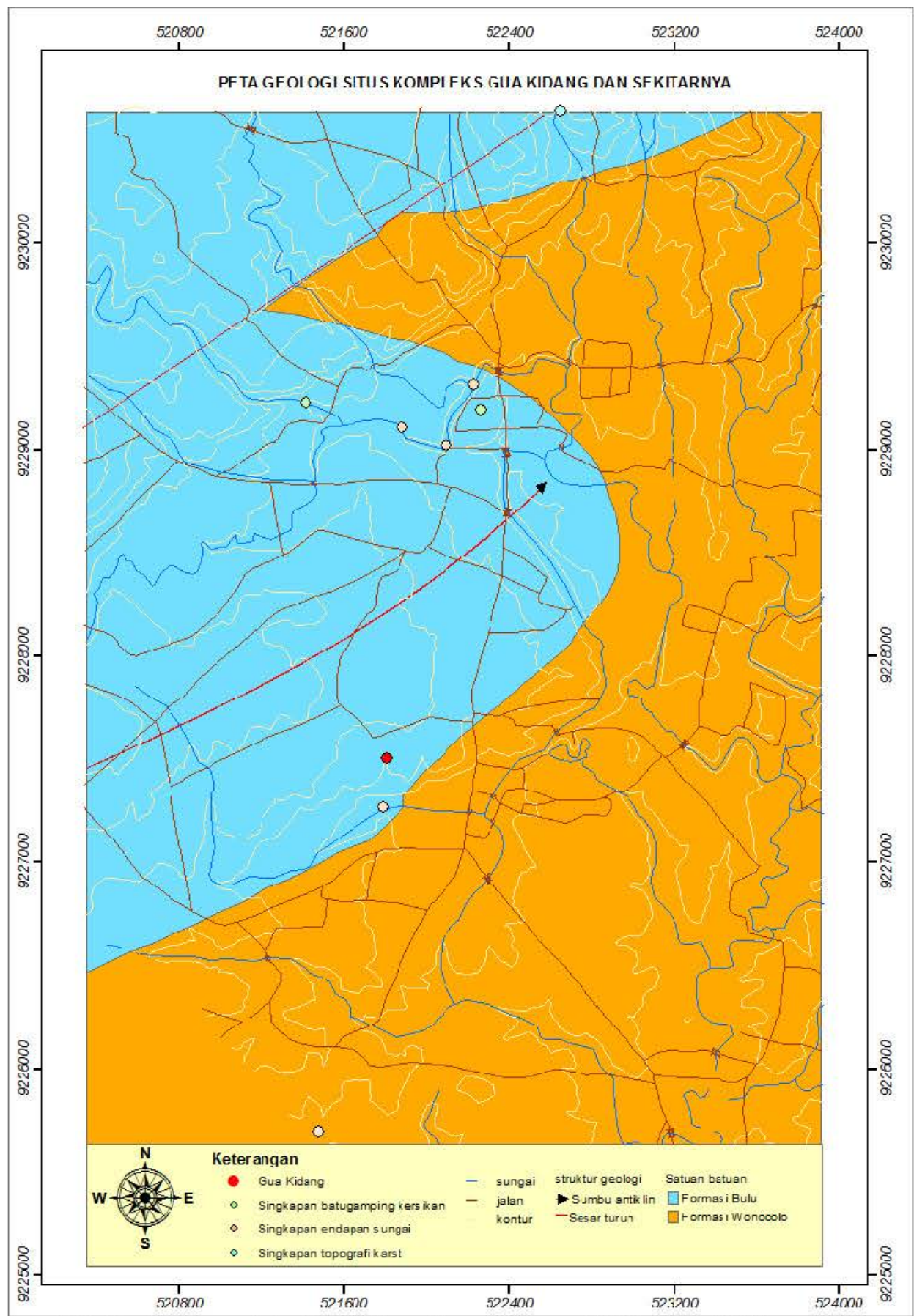

Peta Geologi korrpleks Gun Kidang dan sekitarrya (oleh Agus Tri Hascaryo) 
Kondisi geologis geografis Gua Kidang dan sekitarnya ini mempengaruhi pola hidup manusia prasejarah dalam mempertahankan hidupnya. Gua Kidang telah diteliti selama lima tahap untuk mengetahui pola okupasi yang terjadi dalam komunitas penghuni gua kawasan karst Blora umumnya dan Todanan khususnya. Berdasarkan hasil survei yang menjangkau seluruh potensi alam terutama gua dan ceruk di kawasan karst Blora, disimpulkan bahwa gua-gua di kawasan karst Blora minim gua hunian. Hal tersebut didasarkan pada kajian morfologi gua, sirkulasi udara dan sinar matahari masuk, temuan permukaan dan pengupasan, serta morfologi lahan sekitar gua (Nurani dan Yuwono, 2008). Sebagian besar gua yang ada di kawasan karst Blora merupakan rekahan bukit, sungai bawah permukaan, dan gua-gua vertikal (sumuran) sebagai sumber air. Ditinjau dari aspek kelayakan hunian gua-gua tersebut tidak layak huni, selain kondisinya lembab gua-gua tersebut masih merupakan sungai bawah permukaan yang aktif, sehingga jejak-jejak aktivitas tidak tampak dari temuan permukaan dan pengupasan. Satu-satunya gua yang memiliki indikasi hunian hanya Gua Kidang. Indikasi hunian tersebut meliputi temuan permukaan berupa fragmen keramik, tembikar, cangkang moluska dan tulang. Oleh karena itu, gua ini diteliti lebih lanjut melalui ekskavasi.

Penelitian dengan melakukan ekskavasi pada beberapa kotak gali di Gua Kidang menghasilkan beberapa temuan yang memberikan gambaran tentang pola hidup manusia prasejarah dalam mempertahankan hidupnya. Tulisan ini akan membahas beberapa hal terkait dengan hasil penelitian Gua Kidang yaitu:

> Bagaimana pola adaptasi manusia penghuni Gua Kidang dalam mempertahankan hidupnya?

> Sejauh mana jelajah manusia penghuni Gua Kidang dalam mencari sumber makanan dan sumber bahan baku untuk peralatan sehari-hari?

$>$ Bagaimana perkembangan teknologi dalam pembuatan peralatan?

\section{POLA HIDUP PENGHUNI GUA KIDANG}

Berdasarkan hasil survei dan ekskavasi sampai pada tahap kelima tahun 2011 ini, dapat diinterpretasikan beberapa hal. Interpretasi tersebut didasarkan pada berbagai data, baik data geologis - geografis maupun data arkeologis. Pertama, manusia penghuni Gua Kidang dalam mempertahankan hidupnya melakukan penjadwalan musim untuk mengkonsumsi pangan (Nurani dan Hascaryo, 2010a). Hal tersebut terkait dengan sumberdaya alam sekitarnya yang menyediakan bahan pangan binatang-binatang invertebrata berupa kerang dan siput pada musim kering, dan binatang-binatang vertebrata pada musim basah. Kesimpulan tersebut diperkuat dengan bukti stratigrafis yang menunjukkan bahwa lapisan atas didominasi temuan fragmen cangkang kerang dan siput, sedangkan lapisan bawah didominasi temuan fragmen tulang, dan gigi binatang darat vertebrata. 
Kedua, dalam pengembangan teknologi untuk pembuatan peralatan sehari-hari tampak adanya tingkat teknologi yang lebih maju dibandingkan teknik pengerjaan dan variasi alat dari cangkang kerang dan tulang di gua-gua hunian prasejarah lainnya di Jawa. Hal yang menarik dari aspek bahan untuk peralatan sehari-hari adalah minimnya peralatan dari batu atau litik. Hal tersebut disebabkan sumber bahan baku batu tidak berkembang baik di lingkungan sekitar Gua Kidang khususnya, dan kawasan karst Todanan umumnya (Nurani dan Hascaryo, 2010b).

Ketiga, berkenaan dengan pola pemanfaatan lahan Gua Kidang tampak bahwa gua dimanfaatkan oleh beberapa kelompok. Interpretasi tersebut didasarkan pada sebaran temuan di tiap-tiap kotak gali. Secara kuantitas dan kualitas sebaran temuan menunjukkan persamaan antarlahan (sebaran horisontal), sedangkan secara vertikal (waktu) terdapat perbedaan temuan antarlapisan. Berdasarkan hal tersebut, maka disimpulkan bahwa pemanfaatan lahan bukan dibagi tiap-tiap lahan untuk aktivitas tertentu, namun tiap-tiap lahan ditempati satu kelompok (Nurani dan Hascaryo, 2010a).

Beberapa kesimpulan di atas dipertegas dengan hasil penelitian tahap kelima yang dilakukan bulan April 2011. Selain itu, berdasarkan berbagai temuan yang semakin variatif baik dari jenis fauna maupun tingkat teknologi yang diterapkan dalam pembuatan alat sehari-hari, muncul beberapa permasalahan baru yang perlu pengkajian lebih dalam. Satu hal yang menonjol adalah temuan jenis fauna seperti Stegodon, Elephas, dan kerang laut. Temuan tersebut menimbulkan dugaan mengenai wilayah

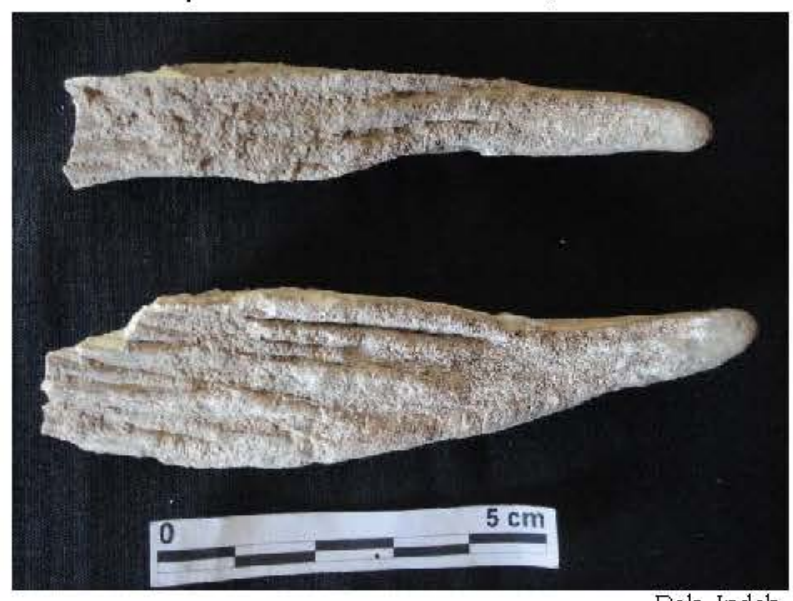
Fragmen gigi stegodon dan Elephas temuan dari kotak B2U7 jelajah manusia penghuni Gua Kidang dalam mempertahankan hidupnya, dan mengeksploitasi lingkungan alam sekitarnya. Berikut akan dikaji sejauh mana jelajah manusia penghuni Gua Kidang dalam mencari sumber pangan dan sumber bahan baku alat, serta perkembangan teknologi yang diterapkan dalam pembuatan alat sehari-hari. 


\section{A. Sumber Pangan dan Sumber Bahan Baku Alat}

Gua Kidang pada awalnya merupakan aliran sungai bawah permukaan, selanjutnya mengalami pengeringan dan tidak berfungsi lagi, sehingga dasar gua tertutup oleh endapan agregat tanah. Material agregat berukuran butir pasir halus sampai lanau mengendap bersama air permukaan dan run off yang masuk ke dalam gua. Selain itu proses sedimentasi juga terbentuk oleh media angin. Lahan gua dalam kondisi kering dengan intensitas sinar matahari masuk sekitar $30 \%$ membuat lokasi ini layak dan nyaman untuk digunakan sebagai tempat tinggal. Selain itu ukuran ruangan yang cukup luas dengan ketinggian atap gua kurang lebih 15 meter, menambah kenyamanan dalam pemanfaatan lahan gua dalam melakukan aktivitas sehari-hari. Bukti-bukti kenyamanan lahan Gua Kidang dibuktikan dengan ditemukannya tinggalan-tinggalan arkeologis masa prasejarah.

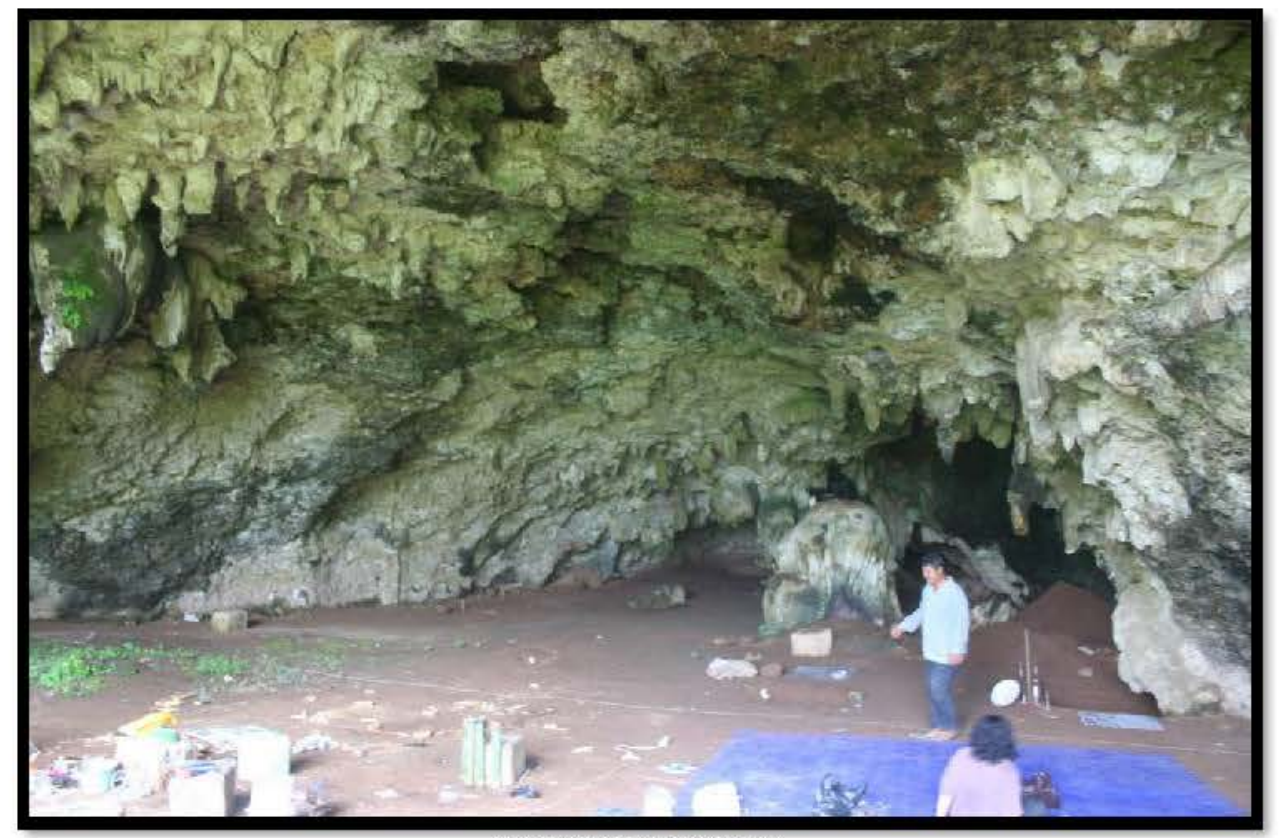

LAHAN GUA KIDANG

dok. Balar Jogja

Temuan arkeologis di gua ini berupa cangkang kerang Pelecypoda, Gastropoda, tulang-tulang binatang, fragmen tembikar, rangka manusia, dan batuan-batuan. Bukti tinggalan kehidupan masa prasejarah sangatlah penting untuk mengungkapkan aspek-aspek sosio-budaya dan kepiawaian teknologi yang mereka miliki sebagai kesatuan ekologi masa itu. Kerang Pelecypoda dan Gastropoda adalah bukti konsumsi manusia prasejarah pendukung Gua Kidang. Kerang atau moluska tampaknya tidak hanya didapat dari sungai dan rawa sekitar gua, namun beberapa cangkang menunjukkan adanya eksplorasi lebih jauh yaitu di laut. Dalam hitungan 
jarak lurus antara gua dengan pantai terdekat yaitu di sebelah utaranya kurang lebih $50 \mathrm{~km}$. Begitu pula temuan tulang binatang dari yang berukuran kecil seperti binatang avis (unggas), cervidae (kijang) hingga binatang berukuran besar seperti bovidae menunjukkan intensitas eksplorasi manusia saat itu sangat tinggi.

Sisa-sisa makanan baik berupa cangkang maupun tulang tidak begitu saja dibuang sebagai sampah, namun dengan teknologi yang dimiliki, mereka mampu mengolah limbah menjadi peralatan sehari-hari. Peralatan sehari-hari manusia pendukung gua antara lain berupa lancipan tulang, lancipan kerang, serut tulang, gurdi tulang, gergaji kerang, dan perhiasan (manik-manik) kerang dan tulang. Hal ini menunjukkan bahwa mereka mampu beradaptasi pada ekosistem masa itu sehingga menghasilkan peralatan yang mereka butuhkan. Selain itu teknik pengerasan alat dengan cara membakar dan pengupaman serta mengasah alat pun dilakukan. Hal tersebut membuktikan tingkat kecerdasan manusia saat itu dan bagaimana mereka mengeksploitasi alam. Perapian tampaknya merupakan prasarana yang menonjol dalam kehidupan di dalam gua, selain digunakan sebagai penghangat ruangan, memasak, juga menjadi bagian dari proses teknik pembuatan alat.

Sebagaimana diketahui pola hidup manusia prasejarah sangat dipengaruhi oleh potensi ekologis sumberdaya alam sekitarnya. Perkembangan teknologi pun didasarkan pada pengelolaan bahan baku yang tersedia di lingkungan alam sekitarnya. Berbagai temuan baik artefak maupun ekofak dari bahan (baca: materi) yang tidak tersedia di lingkungan alam sekitar memunculkan pertanyaan: sejauh mana mobilitas manusia saat itu dalam mempertahankan hidupnya dan di mana sumber bahan pangan dan bahan baku untuk peralatan diperoleh?

Peralatan untuk kebutuhan sehari-hari, selain dari bahan cangkang kerang dan tulang binatang, juga menggunakan batu. Temuan batu pukul dari andesit merupakan salah satu bukti kemampuan untuk memilih bahan yang baik sebagai peralatan. Artinya pemanfaatan lingkungan sekitar tidak hanya sekedar mengambil, tetapi proses pemilihan dilakukan agar bahan dapat dimanfaatkan semaksimal mungkin. Sumber bahan alat batu andesit kemungkinan hanya diambil dari lokasi yang tidak jauh dari Gua Kidang yaitu sekitar aliran Sungai Jaten, Sungai Kedungwungu, dan Sungai Kedungwaru. Jarak antara sungai dengan gua hanya $2-3 \mathrm{~km}$.

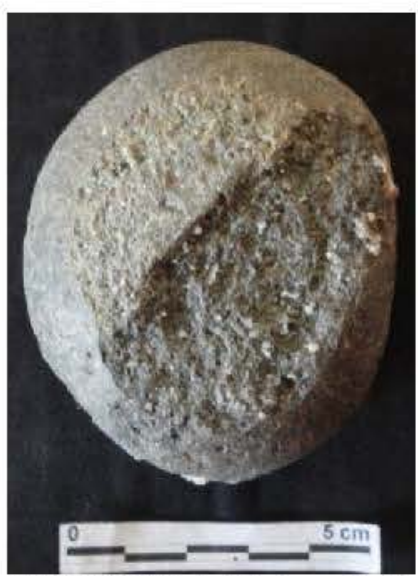

BATU PUKUL dari batu andesit Dok. Indah

Menjadi pertanyaan, bagaimana dengan bahan-bahan batuan yang tidak terdapat di lingkungan sekitar gua, di mana diperolehnya? Bahan artefak batu yang tidak terdapat di sekitar gua antara lain adalah rijang merah dan rijang kuning. Sumber bahan tersebut terdapat di sekitar daerah 
aliran Bengawan Solo. Walaupun ukurannya kerakal hingga brangkal, bahan ini dapat digunakan sebagai peralatan seperti serpih, pisau atau disebut bilah, dan serut sebagaimana yang ditemukan di situs-situs gua prasejarah di Jawa lainnya. Batuan rijang merah dan rijang kuning yang ditemukan pada ekskavasi Gua Kidang sangat intensif digunakan sebagai batu asah alat kerang dan tulang. Hal ini tampak pada temuan batu rijang yang mempunyai garis-garis keausan yang disebabkan oleh pengasahan. Bukti temuan terak-terak rijang adalah sisa-sisa atau residu batuan yang dihasilkan pada saat pengasahan.

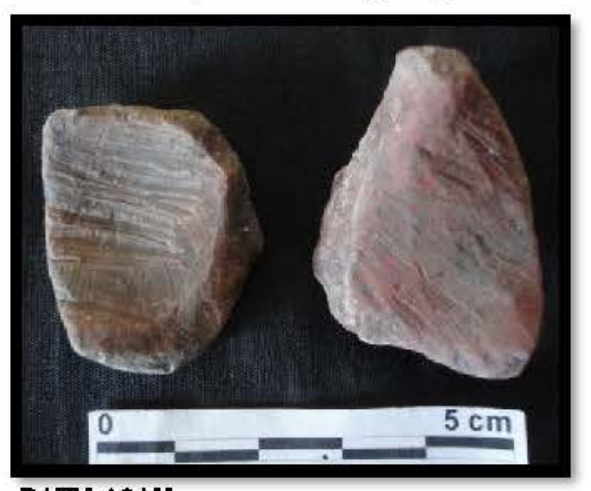

BATU ASAH

Dok. Indah

Bukti tersebut apabila
dikorelasikan dengan kenampakan
slicent slide pada alat tulang dan
kerang, maka terbukti bahwa manusia
pendukung gua memiliki kekhususan
dalam pemakaian batuan silica seperti
rijang. Batuan tersebut tampaknya
hanya sebagai bahan pendukung pada
perkakas tulang dan kerang atau
secondary material yang sangat
berbeda dengan teknologi manusia
penghuni gua-gua prasejarah di
Indonesia pada umumnya. Di lain pihak, tingkat teknologi yang diterapkan pada pembuatan perkakas dari cangkang kerang dan tulang memiliki tingkat yang lebih tinggi dibandingkan dengan teknik pengerjaan peralatan dari cangkang kerang dan tulang temuan dari situs-situs gua di Jawa khususnya dan Indonesia umumnya. Berdasarkan hal tersebut, dugaan yang diajukan bahwa teknologi pembuatan alat batu yang dikenal penghuni Gua Kidang diterapkan pada teknologi pembuatan perkakas dengan bahan baku cangkang kerang dan tulang cenderung kuat kebenarannya (Nurani dan Hascaryo, 2011). Lebih lanjut akan diuraikan tentang tingkat teknologi yang diterapkan pada pembuatan alat-alat dari cangkang kerang dan tulang.

\section{B. Teknologi Pembuatan Alat}

Berdasarkan hasil ekskavasi sampai pada tahap kelima, alat-alat yang diproduksi penghuni Gua Kidang didominasi alat-alat dari cangkang kerang dan tulang. Teknologi pembuatan alat relatif maju dibandingkan teknologi pengerjaan alat-alat cangkang kerang dan tulang temuan situssitus gua lainnya di Jawa. Sebagian besar alat-alat dari cangkang kerang temuan dari situs-situs gua di Jawa adalah serut berbentuk bulan sabit. Selain itu, jenis kerang yang dimanfaatkan untuk membuat peralatan seharihari sebagian besar dari jenis klas pelecypoda. Hasil ekskavasi di Gua Kidang menghasilkan temuan alat-alat cangkang kerang dengan jenis alat yang lebih bervariasi meliputi serut, serut samping, serut cekung, lancipan, serut lancipan, penusuk, dan beberapa alat yang diberi lubang serta 
perhiasan. Bahan cangkang yang dimanfaatkan untuk membuat peralatan pun juga lebih bervariasi, tidak hanya dari klas pelecypoda saja, namun juga dari jenis klas gastropoda.

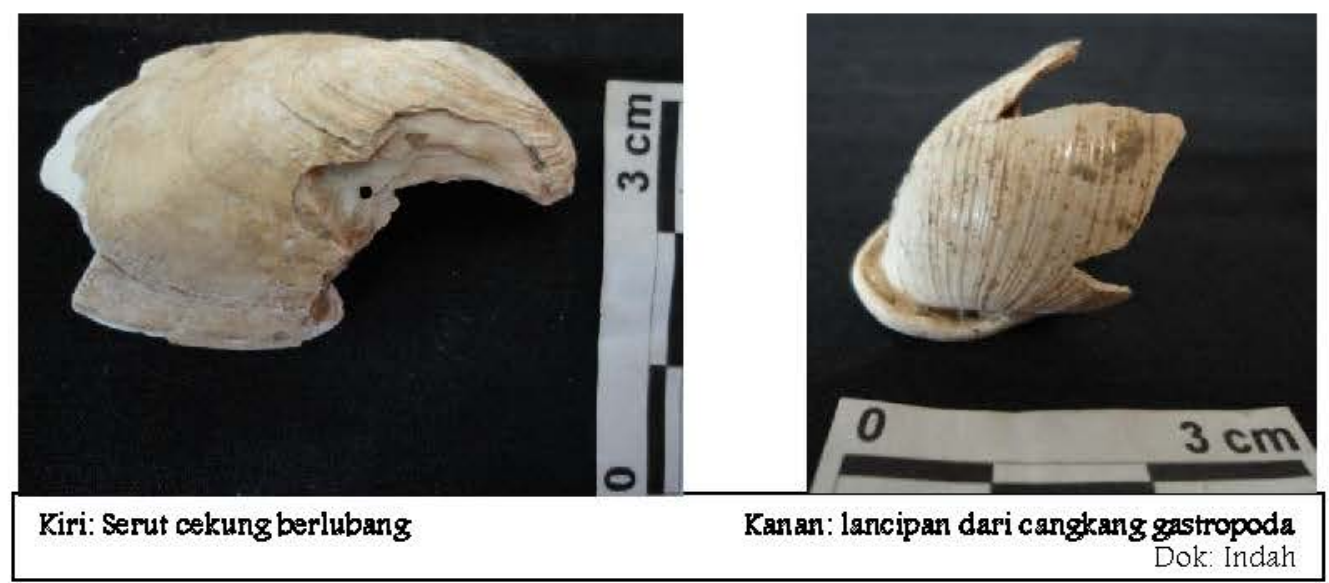

Pada teknik pengerjaan alat dari cangkang kerang tampak adanya persamaan dengan teknik pangkas dan retus yang diterapkan pada alat-alat

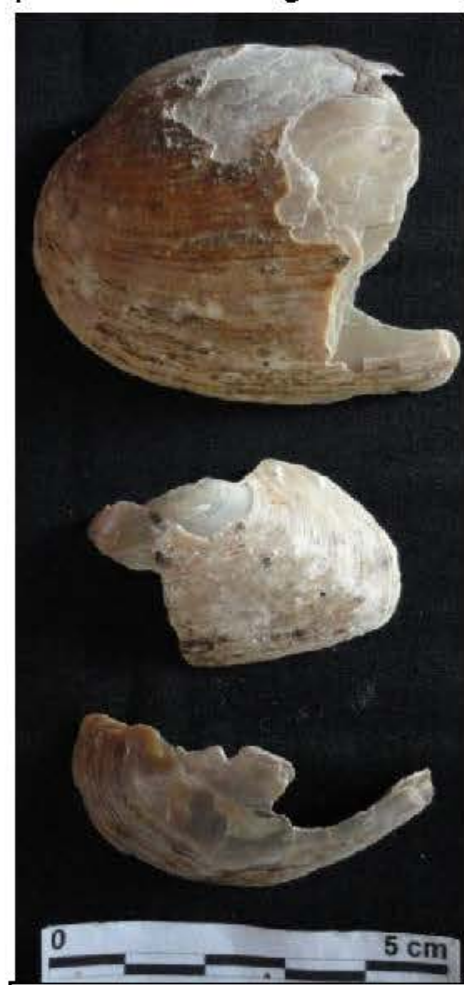

Peryempurnaan alat dengan pengesahan, pembakaran, dan pengelupasan kulit luar cangkang kerang

perhiasan atau manik-manik.

Dok. Indah dari batu atau litik. Pengerjaan cangkang pada satu sisi ataupun seluruh sisi dikerjakan secara intensif dengan pangkasan primer. Selanjutnya pengerjaan dengan retus atau pangkasan sekunder dilakukan untuk mempertajam alat. Selain itu, pada beberapa alat juga dibuat kait atau tangkai yang mungkin untuk disambungkan pada tangkai atau tongkat, sehingga alat ini merupakan tombak atau mata panah. Hal yang menarik dari pengerjaan alat dari cangkang kerang ini adalah pengelupasan kulit luar cangkang dan pembakaran, serta pengupaman alat. Perlakuan tersebut kemungkinan dimaksudkan untuk ketajaman dan memperkuat alat agar bertahan digunakan. Karakter lainnya dari alat-alat cangkang Gua Kidang ini adalah pada beberapa alat dibuat lubang pada satu bagian tertentu. Pembuatan lubang pada alat diduga sebagai tempat untuk mengaitkan tali, sehingga alat tersebut dapat dikalungkan atau dijadikan gelang. Dengan menggantungkan alat pada seutas tali tersebut mempermudah alat dibawa kemanamana. Selain itu, pembuatan lubang pada cangkang kerang bukan alat, kemungkinan diperuntukkan sebagai 
Dalam pembuatan alat dari tulang tampak bahwa teknikteknik pengerjaan pembuatan alat batu juga diterapkan. Hal tersebut tampak jelas pada temuan bilah dari tulang. Specimen ini awalnya merupakan spatula dengan ciri teknik pengupaman pada bagian tajaman yang telah dilakukan dengan sempurna. Selanjutnya

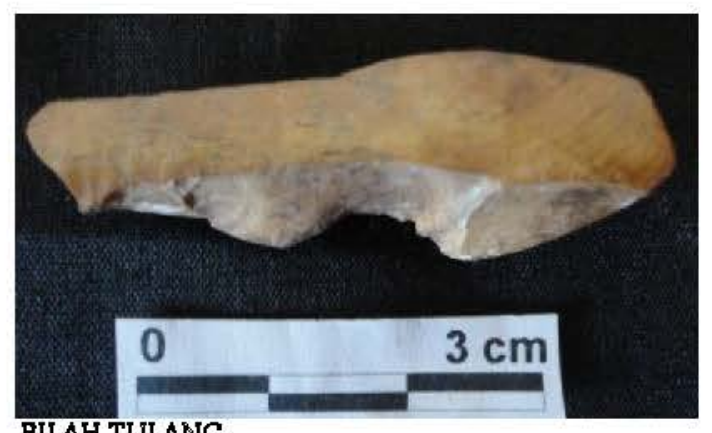

BILAH TULANG

Dok. Indah spatula tersebut dikerjakan lagi dengan beberapa pangkasan primer dan diperhalus dengan pangkasan sekunder yaitu retus-retus pada satu sisi, sehingga ukuran panjang mencapai dua kali ukuran lebar. Tanda-tanda bahwa bilah tulang ini awalnya merupakan spatula masih tampak jelas.

Temuan lainnya yang menunjukkan penerapan teknik pembuatan

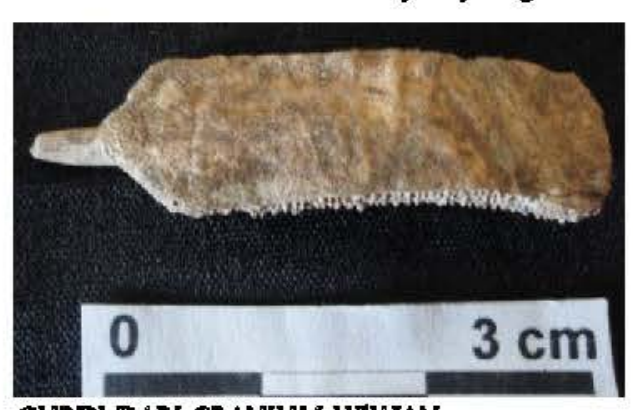

GURDI DARI CRANIUM HEWAN

Dok. Indah

Selain temuan di atas, tampak juga alat dari canine (gigi taring) suidae yang dikerjakan dengan menerapkan teknik pengerjaan alat batu. Alat ini adalah lancipan. Setelah dipangkas pada bagian yang melengkung dengan pangkasan primer selanjutnya dikerjakan dengan pengerjaan pangkasan sekunder melalui retusretus mikro, sehingga pada satu sisi alat batu dalam pengerjaan alat tulang adalah gurdi temuan dari kotak U31T49. Gurdi ini dibuat dari fragmen tengkorak hewan yang dikerjakan dengan pangkasan berbentuk persegi yang pada bagian sutura yang kokoh dijadikan tajaman, sehingga menjorok. Selanjutnya bagian tajaman ini dikerjakan lagi untuk mempertajam alat.

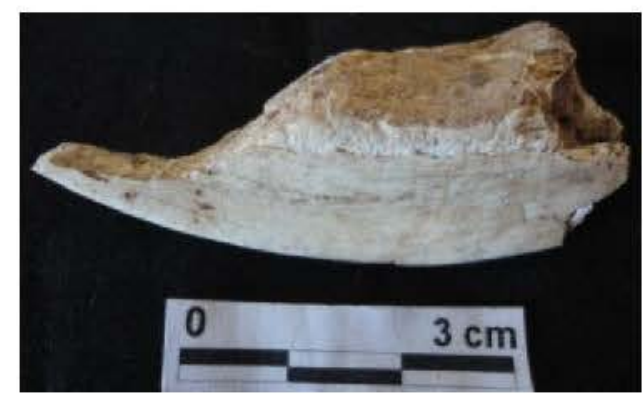

LANCIPAN DARI CANINE SUIDAE

Dok. Indah meruncing.

\section{JANGKAUAN JELAJAH MANUSIA PENGHUNI GUA KIDANG}

Berdasarkan pada bahasan di atas, tampak bahwa manusia penghuni Gua Kidang telah mengeksploitasi alam dalam mempertahankan hidupnya dengan pola adaptasi penjadwalan musim dalam mengkonsumsi 
pangan. Selain itu, beberapa lokasi telah dikelola sebagai sumber pangan dan sumber bahan baku untuk peralatan. Penerapan teknologi untuk pembuatan peralatan pun tampaknya disiasati dengan ketersediaan bahan baku yang ada di sekitarnya, yaitu teknologi pembuatan alat batu yang diterapkan dalam pembuatan peralatan dari cangkang kerang dan tulang. Hal tersebut menghasilkan teknologi relatif "tinggi" dibandingkan dengan teknik pembuatan alat dari cangkang kerang dan tulang yang diproduksi oleh penghuni gua-gua lainnya di Jawa. Selain itu, variasi jenis alatnya pun lebih bervariasi dengan jenis-jenis alat sebagaimana alat-alat batu yang dikembangkan manusia penghuni gua-gua di Jawa umumnya, yaitu meliputi serut, serut samping, serut cekung, lancipan, gurdi, serut lancipan dan serut bergerigi, serta pengasah.

Alat-alat batu atau litik sebagai karakter budaya hunian gua masa prasejarah yang dikenal dengan istilah mesolitik antara lain serpih bilah tidak diproduksi oleh penghuni Gua Kidang. Hal tersebut disebabkan lingkungan alam sekitamya tidak menyediakan bahan baku batu dengan silikaan tinggi. Namun demikian, manusia penghuni Gua Kidang juga memproduksi alat-alat batu dari batu rijang yang ada di sekitar gua sebagai alat penunjang yaitu sebagai batu asah alat-alat cangkang kerang dan tulang.

Batu rijang meskipun hanya sebagai bahan baku penunjang dalam ekosistem pola hidup manusia penghuni Gua Kidang, namun tidak dapat diabaikan begitu saja. Hal tersebut disebabkan batu rijang merupakan bahan baku yang dibutuhkan dalam kehidupan sehari-hari. Sumber bahan baku batu rijang terdekat sebagaimana telah diuraikan di atas diduga berada di Bengawan Solo, berjarak sekitar $30-40 \mathrm{~km}$. Jika dugaan ini benar, artinya bahwa wilayah jelajah manusia pendukung Gua Kidang beradius 30 hingga $50 \mathrm{Km}$. Menurut teori chatcment area jarak radius tersebut tergolong cukup jauh (Higgs and Finzi, 1972). Untuk lebih dapat menginterpretasikan, sejauh mana daya eksploitasi manusia prasejarah gua ini, maka diperlukan survei dan penelitian lebih lanjut. Terutama pada lokasi-lokasi yang berada di antara Gua Kidang dengan daerah pantai (sumber makan) maupun Bengawan Solo (sumber bahan baku alat).

Di lain pihak berdasarkan temuan fragmen gigi stegodon dan elephas di kotak B2U7, kemungkinan luasan daerah jelajah tidak hanya sampai pada daerah aliran Bengawan Solo purba saja, tetapi mencapai daerah Pegunungan Muria (Nurani dan Hascaryo, 2011). Pegunungan Muria selatan merupakan lokasi situs plestosen yang dikenal dengan nama Situs Patiayam. Temuan arkeologis maupun paleontologis situs ini antara lain artefak litik dan fosil stegodon dan elephas (Setiawan, Andry, 2001). Jika dikorelasikan dengan temuan paleontologis Gua Kidang berupa geligi stegodon dan elephas dapat diinterpretasikan adanya hubungan antara kedua situs tersebut. Lebih lanjut dapat dilihat gambar di bawah ini yang memperlihatkan jarak jelajah manusia pendukung Situs Gua Kidang yang beradius $50 \mathrm{~km}$ (periksa gambar: Ilustrasi daerah jelajah penghuni Gua Kidang). 


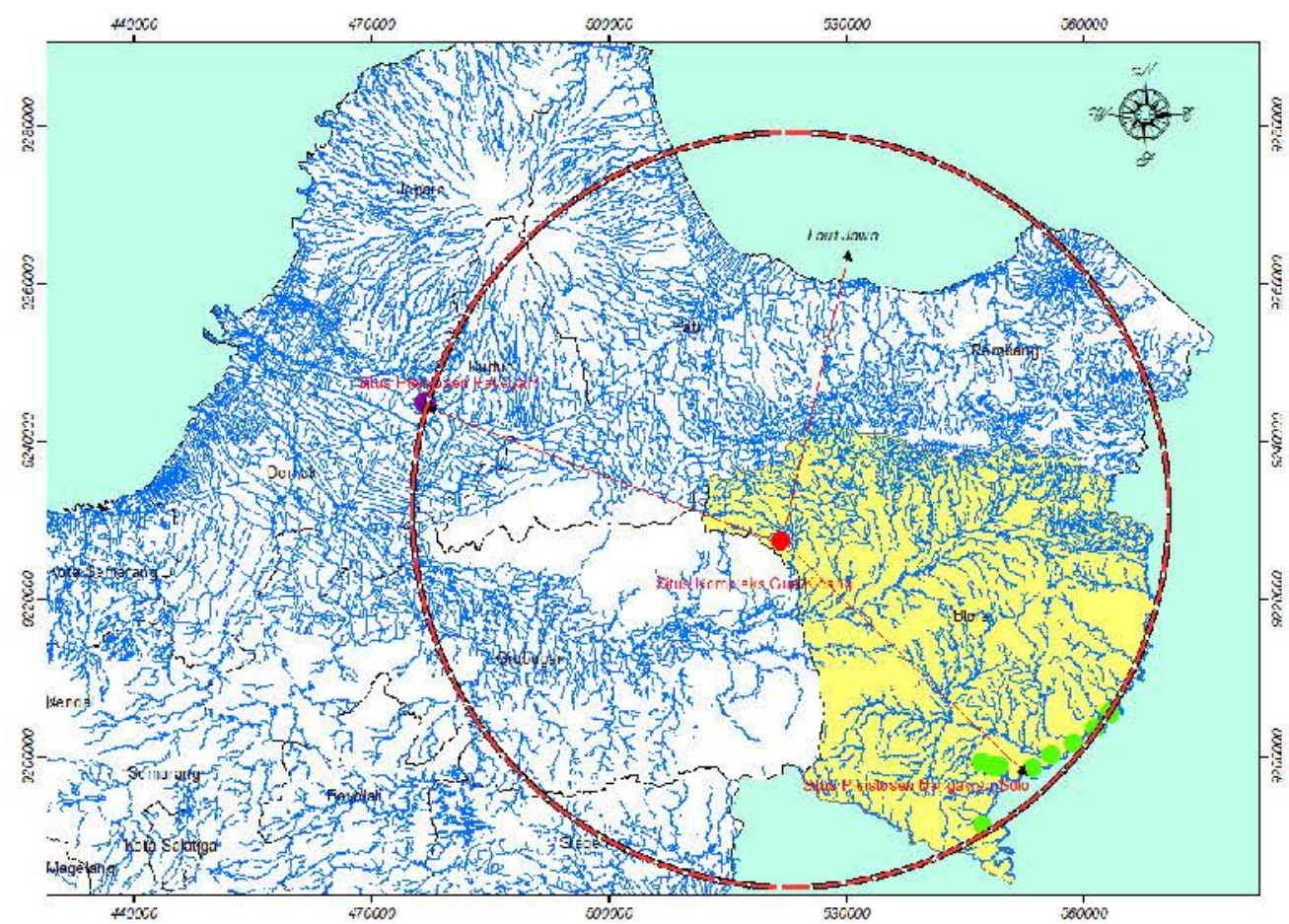

Ilustrasi Daerah Jelajah Penghuni Gua Kidang (oleh: Agus Tri Hascaryo)

Sangatlah menarik jika dicermati kondisi lingkungan purba Situs Patiayam pada 800.000 tahun yang lalu. Penelitian geologi menunjukkan adanya perubahan lingkungan. Masa perubahan lingkungan diakibatkan perubahan iklim global antara interglasiasi dan glasiasi (Sartono, 1978). Kondisi interglasiasi dengan terjadi pencairan es mengakibatkan muka air laut mengalami kenaikan, sehingga terjadi penggenangan di daerah antara daratan Pulau Jawa bagian utara dengan Pegunungan Muria. Sebaliknya terjadi susut laut pada masa glasiasi yang memunculkan daratan di daerah antara tersebut. Walaupun terjadi genangan laut, daerah ini masih dalam katagori laut dangkal. Kondisi paleolingkungan demikian memungkinkan untuk terjadi penjelajahan hominid maupun binatang-binatang.

Di lain pihak jika jangkauan jelajah tersebut benar, maka beberapa situs plestosen di Blora bagian tenggara yang merupakan situs-situs di DAS Solo yaitu situs Jigar, Manden, dan Ngandong juga merupakan jangkauan manusia Gua Kidang. hal tersebut menarik untuk dikaji lebih lanjut mengingat secara periodik situs-situs tersebut merupakan situs sebelum berkembangnya kehidupan di gua atau ceruk. Apakah manusia penghuni Gua Kidang merupakan kelanjutan dari manusia purba yang hidup masih mengembara di DAS Solo? Apabila jawabannya iya, maka evolusi manusia Jawa akan terangkai tanpa putus dari manusia purba menuju manusia prasejarah. Selain itu di bagian selatan Gua Kidang terdapat situs manusia purba Sangiran. Titik-titik pinggiran radius $30-50 \mathrm{~km}$ tersebut menunjukkan 
situs-situs manusia purba dengan budayanya yang berkembang sebelum kehidupan di gua. Untuk menjawab semua itu, diperlukan penelitian lebih mendalam yang melibatkan berbagai disiplin ilmu sehingga kesinambungan budaya dari manusia purba menuju manusia prasejarah akan tejawab.

\section{SIMPULAN}

Berdasarkan uraian tersebut di atas, maka dapat disimpulkan beberapa hal sebagai berikut:

* Pola adaptasi manusia penghuni Gua Kidang dalam mempertahankan hidupnya adalah dengan penjadwalan musim untuk mengkonsumsi pangan. Pada musim kering mereka mengkonsumsi binatang invertebrata yaitu jenis kerang dan siput, sedangkan pada musim basah mereka mengkonsumsi binatang jenis vertebrata. Asumsi tersebut diperkuat dengan bukti stratigrafi, yaitu pada lapisan atas temuan ekskavasi didominasi oleh cangkang moluska spesies kerang dan siput baik berupa artefak maupun ekofak (sisa makanan), sedangkan lapisan bawah didominasi temuan berupa tulang binatang darat terutama jenis vertebrata baik berupa artefak maupun ekofak. Selain itu, proses pengendapan membuktikan pada lapisan bawah terjadi penggumpalan dengan tingkat kelembaban sedang. Dengan kata lain proses pengendapan tersebut disebabkan kondisi tanah yang basah.

* Pola pemanfaatan lahan Gua Kidang, sebaran temuan pada kotakkotak ekskavasi menunjukkan temuan yang relatif sama antarkotak. Perbedaan terlihat pada tiap lapisan tanah, yaitu pada lapisan atas didominasi cangkang moluska, sedangkan lapisan bawah didominasi temuan tulang vertebrata. Kondisi demikian menunjukkan bahwa pemanfaatan lahan gua, tidak didasarkan pada pemanfaatan untuk tiap aktivitas. Kemungkinan pemanfaatan lahan gua dilakukan dengan pembagian lahan untuk aktivitas beberapa kelompok penghuni. Dari bukti tersebut dapat disimpulkan bahwa Gua Kidang dihuni oleh beberapa kelompok atau keluarga yang menempati bagian lahan tertentu untuk setiap kelompoknya, sehingga jejak aktivitasnya relatif sama antarlahan.

* Teknologi yang diterapkan dalam pembuatan alat dari cangkang kerang dan tulang menunjukkan tingkat teknologi relatif tinggi dibandingkan teknik pengerjaan alat kerang dan tulang temuan dari gua-gua lainnya di Jawa. Selain dari segi teknik pengerjaan, jenis alat atau perhiasan yang diproduksi juga memiliki variasi dan tipe yang lebih beragam dibandingkan dengan temuan alat dan perhiasan cangkang kerang dan tulang dari gua-gua di Jawa lainnya. Bahan cangkang yang digunakan untuk peralatan menunjukkan juga pemanfaatan yang maksimal tidak 
hanya dari cangkang kelas pelecypoda, tetapi juga dari kelas gastropoda. Hal tersebut sampai saat ini belum ditemukan di gua-gua hunian lain di Jawa. Adapun alat dari batu atau litik tidak berkembang dengan baik, umumnya alat litik dibuat untuk kebutuhan mengasah cangkang dan tulang sehingga teknik-teknik pangkasan sebagaimana dalam pembuatan serpih - bilah tidak ada. Selain itu bahan baku batu yang tersedia di sekitar gua tidak mencakup bahan batu dengan silikaan tinggi. Sebagian besar bahan baku yang tersedia adalah rijang merah dan kuning, serta batu andesit. Hal tersebut menunjukkan bahwa kedudukan alat batu bukan sebagai alat utama, namun sebagai alat pendukung saja. Namun, berdasarkan teknologi yang diterapkan pada pembuatan alat dan perhiasan dari cangkang kerang dan tulang, tampaknya teknologi pembuatan alat batu diterapkan pada kerang dan tulang. Dengan kata lain, ada dugaan manusia penghuni Gua Kidang mengenal teknologi alat batu yang dikembangkan pada teknik pembuatan dari bahan yang berbeda yaitu cangkang kerang dan tulang.

* Jenis binatang yang dikonsumsi manusia penghuni Gua Kidang terdiri atas spesies invertebrata baik dari air tawar maupun laut dan spesies vertebrata antara lain jenis cervidae, suidae, macaca, bovidae, rodentsia. Temuan yang menarik dari jenis binatang adalah fragmen gigi stegodon dan elephas di kotak B2U7. Kedua jenis binatang ini habitat terdekatnya berada di sekitar Bengawan Solo yang merupakan situs manusia purba kala Plestosen di Sungun, Jigar, Manden, dan Ngandong di Blora bagian tenggara, situs manusia purba di Pegunungan Muria yaitu situs Patiayam, Kudus; dan situs manusia purba di Sangiran. Berdasarkan temuan tersebut menarik untuk ditelusuri seberapa jauh jelajah manusia penghuni Gua Kidang bereksplorasi dalam mempertahankan hidupnya. Selain itu, menarik untuk dikaji lebih mendalam adalah evolusi manusia purba menuju manusia prasejarah yaitu penghuni gua tertua. Data manusia tertua penghuni gua sangatlah penting diungkap, sehingga evolusi manusia dapat terekonstruksi tanpa putus. 


\section{KEPUSTAKAAN}

Higgs, E.S and C. Vita Finzi, 1972. Prehistoric Economies: A Territorial Approach. Cambridge University Press.

Nurani, Indah Asikin, dan Agus Tri Hascaryo, 2010a, LPA Pola Okupasi Gua Hunian Prasejarah Kawasan Karst Blora Tahap IV. Tidak terbit

--_---, 2010b. "Pola Hidup Komunitas Gua Hunian Prasejarah Kawasan Karst Blora" dalam Berkala Arkeologi Edisi Mei (1). Yogyakarta: Balai Arkeologi.

--_--, 2011. LPA Pola Okupasi Gua Hunian Prasejarah Kawasan Karst Blora Tahap V. Tidak terbit

Nurani, Indah Asikin dan J. Susetyo Edy Yuwono, 2008. "Gua Kidang, Pilihan Manusia Prasejarah di Kawasan Karst Blora" dalam Berkala Arkeologi Edisi Mei (1). Yogyakarta: Balai Arkeologi.

Sartono, 1978. Sedimentasi Daerah Patiayam Jawa Tengah. Jakarta: PT Rora Karya

Setiawan, Andry, 2001. "Geologi dan Paleontologi Vertebrata Daerah Patiayam dan Sekitamya di Kecamatan Jekulo, Kabupaten Kudus Jawa Tengah". Skripsi Departemen Teknik Geologi - Fakultas IImu Kebumian dan Teknologi Mineral. ITB 